\title{
calendar of meetings
}

\begin{tabular}{|c|c|c|}
\hline & 1989 & \\
\hline Charleston, S.C. & Mar. 5-7 & $\begin{array}{l}\text { *Workshop on Climate and Agriculture: Systems } \\
\text { Approaches to Decision Making }\end{array}$ \\
\hline Charleston, S.C. & Mar. 7-10 & $\begin{array}{l}\text { *19th Conference on Agricultural and Forest } \\
\text { Meteorology }\end{array}$ \\
\hline Charleston, S.C. & Mar. 7-10 & ${ }^{\star}$ Ninth Conference on Biometeorology and Aerobiology \\
\hline Charleston, S.C. & Mar. 7-10 & ${ }^{\star}$ Sixth Conference on Applied Climatology \\
\hline Tallahassee, Fla. & Mar. 27-31 & *24th Conference on Radar Meteorology \\
\hline Rotorua, New Zealand & Mar. 27-31 & Fourth International Meeting on Statistical Climatology \\
\hline Miami, Fla. & Apr. 5-7 & 11th Annual National Hurricane Conference \\
\hline San Francisco, Calif. & Apr. 10-14 & $\begin{array}{l}\text { * Seventh Conference on Atmospheric and Oceanic } \\
\text { Waves and Stability }\end{array}$ \\
\hline San Francisco, Calif. & Apr. 11-14 & $\begin{array}{l}\text { *Seventh Conference on the Meteorology of the Middle } \\
\text { Atmosphere }\end{array}$ \\
\hline Melbourne, Australia & Apr. 11-12 & $\begin{array}{l}\text { Workshop on Long-Range Weather Forecasts: Quality } \\
\text { and Value }\end{array}$ \\
\hline San Francisco, Calif. & Apr. 15-17 & $\begin{array}{l}\text { Symposium on the Middle Atmosphere in the Southern } \\
\text { Hemisphere (MASH) }\end{array}$ \\
\hline $\begin{array}{l}\text { Ottawa, Ont., } \\
\text { Canada }\end{array}$ & Apr. 17-21 & Tenth Conference on Fire and Forest Meteorology \\
\hline Washington, D.C. & May 2-4 & $\begin{array}{l}\text { Third Workshop on Artificial Intelligence Research in } \\
\text { Environmental Science (AIRIES) }\end{array}$ \\
\hline Baltimore, Md. & May 8-12 & With Spring Meeting of AGU \\
\hline Beijing, China & May 8-12 & $\begin{array}{l}\text { Fifth WMO Scientific Conference on Weather } \\
\text { Modification and Applied Cloud Physics }\end{array}$ \\
\hline Baltimore, Md. & May 10-19 & $\begin{array}{l}\text { International Association of Hydrological Sciences } \\
\text { (IAHS) Third Scientific Assembly }\end{array}$ \\
\hline San Diego, Calif. & May 16-19 & $\begin{array}{l}{ }^{\star} 18 \text { th Conference on Hurricanes and Tropical } \\
\text { Meteorology }\end{array}$ \\
\hline San Diego, Calif. & May 16-19 & $\begin{array}{l}{ }^{\star} \text { Fourth Conference on Satellite Meteorology and } \\
\text { Oceanography }\end{array}$ \\
\hline Bal Harbour, Fla. & May 31 & $\begin{array}{l}\text { *AMS Short Course on Hurricane Forecasting and } \\
\text { Tropical Meteorology for the Media }\end{array}$ \\
\hline Bal Harbour, Fla. & June 1-4 & ${ }^{\star}$ 19th Conference on Broadcast Meteorology \\
\hline $\begin{array}{l}\text { Garmisch- } \\
\text { Partenkirchen, } \\
\text { Fed. Rep. of Germany }\end{array}$ & June 5-9 & $\begin{array}{l}\text { International Conference on Mountain Meteorology and } \\
\text { ALPEX }\end{array}$ \\
\hline
\end{tabular}


Quebec, Canada

Crystal City (Arlington), Va.

Reading, United Kingdom

Seattle, Wash.

Brussels, Belgium

Brussels, Belgium

Hamburg, Fed. Rep. of Germany

Bulgaria

Monterey, Calif.

Monterey, Calif.

Buenos Aires, Argentina

San Francisco, Calif.

Dec. 4-8

To Be Determined

To Be Determined

June 8-9
1990

July 12-16

July 31-Aug. 11

Aug. 21-25

Sept. 4-8

Sept. 4-8

Sept. 11-15

October

Oct. 2-6

Oct. 2-6

Nov. 13-17

January

January
\# +46th Annual Meeting of the Eastern Snow Conference

* Second International Conference on School and Popular Meteorological Education

IAMAP Fifth Scientific Assembly

Symposium on Ice and Climate with the International Glaciological Society

WMO/CIMO Technical Conference TECIMO-IV

COST-73 International Seminar on Weather Radar Networking

International Conference on Modelling of Global Climate Change and Variability

\section{\# + WMO Technical Conference on Monitoring and} Assessment of Changing Composition of the Troposphere

* 12 th Conference on Weather Analysis and Forecasting

*11th Conference on Probability and Statistics

*Third International Conference on Southern Hemisphere Meteorology and Oceanography

With the Fall Meeting of AGU

\#+70th AMS Annual Meeting

\# + Symposium on Global Change Systems

* Meeting administered by AMS. Other meetings AMS cosponsors or cooperates.

\# New listing in Calendar.

+ New listing -- see Announcements/Call for Papers.

\section{Meeting Procedures for Authors \\ (for meetings administered by AMS)}

For meetings that have preprint or extended abstracts volumes, only reviewer's abstracts will be required; abstracts will not be published in the BuLLETIN.

For meetings that do not have preprint or extended abstracts volumes, both reviewer's abstracts and short abstracts (100 words) for inclusion in an abstract booklet to be distributed at the meeting will be required.

Because of time constraints and escalating costs, AMS will no longer accommodate changes in authors' names, affiliations, paper titles, and/or abstracts once the program has been received at AMS from the program chairman.

Programs are now set by computer. Mathematical/chemical equations and/or symbols may not be used in titles and short abstracts. Please substitute words, phrases, or sentences for mathematical and chemical expressions.

Authors are requested to comply with the above procedures. 


\section{Announcements}

\section{Workshop on Climate and Agriculture: Systems Approaches to Decision Making, March 5-7, 1989, Charleston, S.C.}

A workshop on Climate and Agriculture: Systems Approaches to Decision Making, will be held 5-7 March 1989 at the Sheraton Charleston Hotel in Charleston, S.C. The workshop will precede the 19th Conference on Agricultural and Forest Meteorology, the Ninth Conference on Biometeorology and Aerobiology and the Sixth Conference on Applied Climatology to be held 7-10.March 1989 at the same location. The workshop is being partially supported by the U.S. Dept. of Agriculture, USDA Extension Service, USDC National Climate Program Office, Campbell Scientific, Inc., and the Farm Foundation, with the cooperation of the American Meteorological Society.

The overall goal of this workshop is to establish a research base and a framework for further research and applications in systems approaches to climate-related decision making in agriculture.

Registration for the workshop is separate from that of the three concurrent conferences and will be handled by AMS (45 Beacon St., Boston, MA, 02108). As of 1 February, 1989 , registration fees are $\$ 85$ for professionals and $\$ 40$ for students. For further information about the workshop, contact Dr. Albert Weiss, CAMaC-245 LW Chase, Univ. of Nebraska, Lincoln, NE 68583-0728 (tel.: 402-472-6761).

The program was published in the January 1989 Bulletin. $(10 / 88 ; r 2 / 89)$

\section{9th Conference on Agricultural and Forest Meteorology, March 7-10, 1989, Charleston, S.C.}

The 19th Conference on Agricultural and Forest Meteorology, sponsored by the American Meteorological Society, will be held 7-10 March 1989 at the Sheraton Charleston Hotel in Charleston, S.C. The meeting will be held in conjunction with the Ninth Conference on Biometeorology and Aerobiology and the Sixth Conference on Applied Climatology, and will be preceded by a workshop on Climate and Agriculture: Systems Approaches to Decision Making (see above announcement).

The program will include general sessions on: 1) Crop microclimate; 2) Forest meteorology; 3) Evapotranspiration and energy balance; 4) Operational forecasting; and 5) Applications of remote sensing in agriculture and forestry. Two symposia have also been scheduled.

The deadline for abstracts has passed. A preprint volume will be prepared in advance and distributed at the conference.

A block of rooms has been reserved at the Sheraton Charleston Hotel at special conference rates of $\$ 52 /$ single, $\$ 62 /$ double, plus $7 \%$ tax. Make reservations directly with the hotel at 170 Lockwood Dr., Charleston, S.C. 29403 (tel.: 803-723-3000).

Local Arrangements Chairperson is Dr. Dale Linvill, 137 McAdams Hall, Clemson, SC 29634-0357 (tel.: 803-6564070). Additional information can be obtained from the Program Chairperson, Dr. Katharine B. Perry, North Carolina State Univ., Box 7609, Raleigh, NC 27695-7609 (tel.: 919-737-3537) or from the Conference General Chairperson, Dr. Edward T. Kanemasu, Evapotranspiration Lab.,
Waters Annex, Kansas State Univ., Manhattan, KS 66506 (tel.: 913-532-5731). (2/88;r3/89)

The program was published in the November 1988 Bulletin.

\section{Ninth Conference on Biometeorology and Aerobiology, March 7-10, 1989, Charleston, S.C.}

The Ninth Conference on Biometeorology and Aerobiology, sponsored by the American Meteorological Society, will be held 7-10 March 1989 at the Sheraton Charleston Hotel in Charleston, S.C., in conjunction with the 19th Conference on Agricultural and Forest Meteorology and the Sixth Conference on Applied Climatology, and will be preceded by a workshop on Climate and Agriculture: Systems Approaches to Decision Making (see above announcement).

The conference will include sessions on aerobiology, the effects of weather and climate on components of the biosphere, the contributions of biological processes to climate change questions as indicators or causes, human and urban biometeorology, and physiological ecology. A joint session will be held with the Sixth Conference on Applied Climatology.

The deadline for abstracts has passed. A preprint volume will be prepared in advance and distributed at the conference.

See above for information on hotel and registration arrangements. The Program Chairperson is Dr. Dennis Driscoll, Dept. of Meteorology, Texas A\&M Univ., College Station, TX 77840 (tel.: 409-845-7671); and the Local Arrangements Chairperson is Dr. Dale Linvill, 137 McAdams Hall, Clemson, S.C. $29634-0357$ (tèl.: 803-6564070).

The program was published in the November 1988 Bulletin. $(3 / 88 ;$;3/89)

\section{Sixth Conference on Applied Climatology, March 7-10, 1989, Charleston, S.C.}

The Sixth Conference on Applied Climatology, sponsored by the American Meteorological Society, will be held 710 March 1989 at the Charleston-Sheraton Hotel in Charleston, S.C. It will be held concurrently with the 19th Conference on Agricultural and Forest Meteorology and the Ninth Conference on Biometeorology and Aerobiology, and will be preceded by a workshop on Climate and Agriculture: Systems Approaches to Decision Making (see above announcement).

Areas of emphasis will include climatic records, biological and social responses to climatic fluctuation, the use of climate as a national resource in both the public and private sectors and the role of applied climatology in the climatic change problem, and future directions in applied climatology research. A joint session will be held with the Ninth Conference on Biometeorology and Aerobiology.

The deadline for abstracts has passed. A preprint volume will be prepared in advance and distributed at the conference. Please see the 19th Conference on Agriculture and Forest Meteorology listing for hotel and reservation information.

For further information, contact the Program Chairperson, 
Dr. Patrick J. Michaels, Dept. of Environmental Sciences, Clark Hall, Univ. of Virginia, Charlottesville, VA 22903 (tel.: 804-924-7761).

The program was published in the November 1988 Bulletin. $(1 / 88 ; \mathrm{r} 3 / 89)$

\section{4th Conference on Radar Meteorology, March 27-31, 1989, Tallahassee, Fla.}

The 24th Conference on Radar Meteorology, sponsored by the American Meteorological Society, will be held 27-31 March 1989 at the Tallahassee Hilton Hotel in Tallahassee, Fla. The Dept. of Meteorology at Florida State Univ. and the SuperComputer Computations Research Inst. (SCRI) will be the local hosts.

The AMS Committee on Atmospheric Electricity and the Committee on Radar Meteorology sought papers relating aspects of lightning and electrification to radar data. Additional special emphasis will be given to topics related to convective dynamics and applications of the emerging NEXRAD technology.

The deadline for abstracts has passed. A preprint volume will be prepared in advance and distributed at the meeting.

A block of rooms has been reserved at the Tallahassee Hilton Hotel at the special conference rate of $\$ 52 /$ single, $\$ 62 /$ double, plus 8\% tax. Make reservations directly with the hotel at: $101 \mathrm{~S}$. Adams, Tallahassee, FL 32301 (tel: (904) 224-5000).

For program information, contact the Program Committee Cochairperson, Dr. Peter S. Ray, Dept. of Meteorology, Florida State Univ., Tallahassee, FL 32306 (tel.: 904-6441894).

The conference program was published in the December 1988 issue of the Bulletin. (12/88;r1/89).

\section{Fourth International Meeting on Statistical Climatology, March 27-31, 1989, Rotorua, New Zealand}

The Fourth International Meeting on Statistical Climatology (4IMSC), organized and hosted by the New Zealand Meteorological Service, will be held 27-31 March 1989 at the Quality Inn, Rotorua, New Zealand. The meeting is cosponsored by the American Meteorological Society, the World Meteorological Organization, the New Zealand Statistical Association, and the New Zealand Meteorological Society.

Invited speakers include L. S. Gandin, R. E. Livezey, M. R. Leadbetter, K. Hasselman, K. Fraedrich, H. van Loon, and $P$. D. Jones, who will give lead papers in sessions on quality control and spatial variability; multivariate analysis; univariate models; nonlinear analysis; computer graphics and statistical software; detecting shifts, trends, and periodicities; and sources of climate information.

Current prices for accommodation for two persons (subject to inflation/exchange rate fluctuations/reduced rate negotiations) are (US)\$60 at the IMSC venue and (US)\$35 at an adjacent motel (self-catering facilities).

Other inquiries should be addressed to Dr. John Revfeim, Convenor Organizing Committee 4IMSC, P.O. Box 722, Wellington, New Zealand. Those attending the Roturoa conference are also referred to the announcement for the
11-12 April Workshop on Long-Range Weather Forecasts in Melbourne, Australia. $(11 / 87 ; \mathrm{r} 5 / 88)$

\section{1th Annual National Hurricane Conference, April 5-7, 1989, Miami, Fla.}

The 11th Annual National Hurricane Conference, sponsored by the American Meteorological Society, NOAA, and a number of other agencies and organizations, will be held 5-7 April 1989 at the Hyatt Regency Miami, Miami, Fla. Subjects considered for workshops and general presentations included awareness programs, coastal building codes, coastal resorts, damage assessment, debris removal, disaster assistance, emergency communications, emergency medical care, engineering concerns, evacuation, forecasting, hospitals/nursing homes, hurricane exercises, insurance, legal problems, marinas/small boats, media relations, meteorology, mitigation strategies, problems of industry, public response, role of fire departments, role of law enforcement, sheltering, and other hurricane-related topics. The deadline for abstracts has passed.

The 1989 National Hurricane Conference Awards Committee is soliciting nominations for the following awards: Neil Frank Award; the Distinguished Service Award; the Emergency Management Award; and the Legislative Achievement Award. One-page nominations should be accompanied by supportive materials and include the full name, address, title, organization, and business telephone number of both the nominee and the person making the nomination.

To receive more information, or to submit nominations, contact the National Hurricane Conference, 864 East Park Ave., Tallahassee, FL 32301 (tel.: 904-222-7677). (10/ $88 ; \mathrm{r} 12 / 88)$

\section{Seventh Conference on Atmospheric and Oceanic Waves and Stability, April 10-14, 1989, San Francisco, Calif.}

The Seventh Conference on Atmospheric and Oceanic Waves and Stability, sponsored by the American Meteorological Society and organized by the AMS Committee on Atmospheric and Oceanic Waves and Stability, will be held 10-14 April 1989 at the Cathedral Hill Hotel in San Francisco, Calif. One or more joint sessions with the colocated Seventh Conference on the Meteorology of the Middle Atmosphere (see the following announcement) are planned.

This conference is intended to provide a forum for the discussion of basic problems in the fluid dynamics of atmospheres and oceans. The following three areas will be emphasized: 1) Gravity wave dynamics in the atmosphere and oceans, including the interactions of gravity waves, turbulence, and the large-scale flow; and 2) Potential vorticity dynamics and oceanic general circulation theory; and 3) Stationary and quasi-stationary planetary waves in the atmosphere.

The deadline for abstracts has passed. For more information contact: Dr. Isaac M. Held, Program Chairperson, Geophysical Fluid Dynamics Lab., P.O. Box 308, Princeton, NJ 08542 (tel.: 609-452-6512).

The program was published in the January 1989 Bulletin. $(6 / 88 ; \mathrm{r} 1 / 89)$ 


\section{Seventh Conference on the Meteorology of the Middle Atmosphere, April 11-14, 1989, San Francisco, Calif.}

The Seventh Conference on the Meteorology of the Middle Atmosphere, sponsored by the American Meteorological Society and organized by the AMS Committee on the Middle Atmosphere, will be held 11-14 April 1989 at the Cathedral Hill Hotel in San Francisco, Calif. A joint session with the Seventh Conference on Atmospheric and Oceanic Waves and Stability (see the above announcement) on gravity and planetary wave dynamics is planned.

Papers on significant new observational, theoretical, and modeling results were solicited. Topics on the Middle Atmosphere that will be emphasized at the conference include quasi-biennial and semiannual oscillations, tropical stratospheric waves, tropical/extratropical interactions, advances in 3-D modeling, and polar dynamics and chemistry.

The deadline for abstracts has passed. For more information contact: Dr. Roland A. Madden, Program Chairperson, NCAR, P.O. Box 3000, Boulder, CO 80307 (tel.: 303-497-1360).

The program for the conference was published in the February 1989 Bulletin. $(6 / 88 ; r 3 / 89)$

\section{Symposium on the Middle Atmosphere in the Southern Hemisphere (MASH), April 15-17, 1989, San Francisco, Calif.}

The second Middle Atmosphere in the Southern Hemisphere (MASH) Symposium will be held 15-17 April, 1989 in San Francisco, CA following the American Meteorological Society's Conference on the Middle Atmosphere. The MASH Symposium is being organized under the auspices of the international MAC project (Middle Atmosphere Cooperation). The AMS is a cooperating organization.

The purpose of the symposium is to have an in-depth review by invited speakers of current knowledge of dynamics, transport and photochemistry in the middle atmosphere of the Southern Hemisphere. The symposium will be arranged to allow ample time for discussion.

For further information contact Prof. Carlos R. Mechoso, Dept. of Atmospheric Sciences, University of California Los Angeles, CA 90024 (tel: 213-825-3057) or Dr. A. O'Neill, Meteorological Office, London Road, Bracknell, Berkshire, RG12 2SZ, U.K. (tel: 344-420242, ext. 2212.) $(11 / 88)$

\section{Tenth Conference on Fire and Forest Meteorology, April 17-21, 1989, Ottawa, Ont., Canada}

The Tenth Conference on Fire and Forest Meteorology, jointly sponsored by the Canadian Institute of Forestry and the Canadian Meteorological and Oceanographic Society, will be held 17-21 April 1989 in Ottawa, Ont., Canada. The meeting is being held in cooperation with the Society of American Foresters and the American Meteorological Society, and with the support of the Atmospheric Environment Service, the Canadian Forestry Service, and the Ontario Ministry of Natural Resources.
The theme of the conference is "Fire and Forest Meteorology in a Changing Environment: New Technologies and Concerns." Paper and poster presentations were solicited in the areas of relevant new technologies, smoke management and air quality, forest health and productivity, the effects of climate change, and the effects of new technology on human resources in forestry. Also solicited were papers on traditional subjects such as fire meteorology, fire behavior and danger, prescribed burning, lightning detection systems, fire ecology, fire management and fire climatology.

Abstracts and papers from authors of both oral and poster presentations will be included in a volume of preprint proceedings. The deadline for abstracts has passed.

Manufacturers and distributors of relevant fire or meteorological equipment, as well as computer manufacturers, will display their products during the conference, and space and time will be provided to these companies during the program.

Further information may be obtained from the Program Cochairpersons, Roger B. Street (Atmospheric Environment Service, tel.: 416-739-4786) or Dr. Paul Woodard (Univ. of Alberta, tel.: 403-432-4413). (4/88;r2/89)

\section{Third Workshop on Artificial Intelligence Research in Environmental Science (AIRIES), May 2-4, 1989, Washington D.C.}

The Third Workshop on Artificial Intelligence Research in Environmental Science (AIRIES) cosponsored by the American Meteorological Society, will be held 2-4 May 1989 in Washington D.C. The workshop will incorporate a variety of presentation formats including invited and contributed presentations, panel discussions, and for the first time, laboratory sessions.

Papers were solicited on the following topic areas: demonstrable Al systems, works in progress, knowledge engineering, software engineering, human factors, hardware considerations, data base usage and management, data analysis systems, validation, data quality control, educational considerations, and research issues. For more information, contact: Dr. W.R. Moninger, NOAA, R/E2, 325 Broadway, Boulder, Co. 80303.

An invitation has been extended to individuals or groups who wish to conduct a laboratory session for the benefit of attendees. These will be approximately two hours long and must involve participants by the inclusion of hands-on exercises. The program committee is open to suggestions on the topics that might by covered. Those interested in conducting a laboratory session should contact Dr. Moninger at the address above as soon as possible. (12/88;r2/ 89)

\section{Fifth WMO Scientific Conference on Weather Modification and Applied Cloud Physics, May 8-12, 1989, Beijing, People's Rep. of China} The World Meteorological Organization (WMO), in conjunction with the Chinese State Meteorological Administration, will hold a conference 8-12 May 1989 in Beijing, People's Rep. of China, on weather modification science 
and applied cloud physics. This will be the fifth in the series of conferences on weather modification organized by WMO.

The conference will be organized around four broad topics: 1) Cloud physics applied to weather modification; 2) Studies from other disciplines applied to weather modification; 3) Weather modification; and 4) Cloud physics studies directed toward applications other than weather modification.

An International Program Committee (IPC) is planning the conference. The deadline for abstracts has passed. A Proceedings volume will be available at the conference.

Limited travel support for U.S. scientists may be available from the National Science Foundation. Those seeking assistance should contact AMS headquarters for an application in case funds become available.

For further information, contact: World Meteorological Organization, (R/CLA/3-FIFTH), Case Postale No. 5, CH1211 Geneva 20, Switzerland. (3/88;r1/89)

\section{International Association of Hydrological Sciences (IAHS) Third Scientific Assembly, May 10-19, 1989, Baltimore, Md.}

The IAHS Third Scientific Assembly will be held 10-19 May 1989 in Baltimore, Md. The Assembly, cosponsored by the American Meteorological Society, is intended to provide an interdisciplinary forum for review of the latest developments in the field of hydrology. A series of symposia and computer workshops will bring together international specialists in hydrology and related sciences.

Address all inquiries to Mr. Ivan Johnson, Chairman, TSA Organizing Committee, A. Ivan Johnson, Inc., 7474 Upham Court, Arvada, CO 80003, USA. (11/87)

\section{8th Conference on Hurricanes and Tropical Meteorology, May 16-19, 1989, San Diego, Calif.}

The 18th Conference on Hurricanes and Tropical Meteorology, sponsored by the American Meteorological Society, will be held 16-19 May 1989 at the Catamaran Hotel, Mission Bay, San Diego, Calif. The technical program is being arranged by the AMS Committee on Tropical Meteorology and Tropical Cyclones, and the AMS San Diego chapter will be the local host. The conference is being held in conjunction with the Fourth Conference on Satellite Meteorology and Oceanography; joint sessions are planned.

The conference will focus on all aspects of tropical cyclones, the El Nino-Southern Oscillation, the 40-50 day oscillation, and results from the recent special TAMEX, AMEX, and EMEX experiments. A special session on tropical cyclone motion and a joint session on satellite observations of tropical cyclone location and intensity are planned. To stimulate interaction, two or three debates on important current topics will be held. One or two poster sessions are also planned.

All sessions will be held at the Catamaran Resort Hotel, 3999 Mission Blvd., San Diego, Calif. 92109 (619) 4881081. A block of rooms has been set aside at the special rate of $\$ 68 /$ single and $\$ 80 /$ double, plus $8 \%$ tax. Anticipating an overflow crowd, further accomodations are available from the Bahia Resort Hotel, 998 W. Mission Bay
Blvd., San Diego, (619) 488-0551. A water shuttle service will transport guests of the Bahia to the Catamaran for meetings. Rooms at both hotels are limited, so please make your reservations early. They must be made before 15 April 1989 with a one night's deposit. Please request written confirmation, and mention AMS when making reservations.

Preregistration fees are $\$ 135$ (AMS members, speakers, session chairs), $\$ 150$ (non-members), and $\$ 85$ (students and those over 65 ). The deadline for preregistration is $\mathbf{2 8}$ April 1989. After this date registration rates are $\$ 150$ (AMS members, speakers, session chairs), \$175 (non-members), and $\$ 95$ (students and those over 65 ).

The deadline for abstracts has passed. A volume of conference proceedings will be prepared and distributed at the conference.

For more information, contact: Dr. Gary M. Barnes, Program Chairperson, NCAR, P.O. Box 3000, Boulder, CO 80307 (tel.: 303-497-8959).

A certificate and the Max Eaton prize of $\$ 100$ will be awarded at the joint conference for the best student paper. Papers considered for this award will be judged on content and presentation by a panel of judges appointed by the Program Committee; the award will be made only if a suitable paper is presented. Entrants must be enrolled in a college or graduate school, or have recently graduated. Students wishing to compete for this award must be the sole authors, and they should have indicated their desire to compete when submitting abstracts.

The Banner I. Miller Award will also be awarded at the meeting, if appropriate, for the best published paper relating to hurricane and tropical weather forecasting for the period 1 July 1986 through June 1988.

The program was published in the February 1989 Bulletin. $(5 / 88 ; r 3 / 89)$

\section{Fourth Conference on Satellite Meteorology and Oceanography, May 16-19, 1989, San Diego, Calif.}

The Fourth Conference on Satellite Meteorology and Oceanography, sponsored by the American Meteorological Society, will be held 16-19 May 1989 at the Catamaran Hotel, Mission Bay, San Diego, Calif. The technical program is being arranged by the AMS Committee on Satellite Meteorology and Oceanography, and the AMS San Diego chapter will be the local host. The conference is being held in conjunction with with the 18th Conference on Hurricanes and Tropical Meteorology; joint sessions are planned.

Unlike previous conferences, this conference will focus on the use of satellites for observing the tropical oceans and atmosphere. Papers with a tropical emphasis were solicited, as well as those that addressed the problems of tropical cyclone observation, El Nino-Southern Oscillation, current and future satellite systems (GEOSAT, SSM/I, TOPEX, EOS, TRMM, etc.), and results from recent experiments, such as TAMEX, AMEX and EMEX. Poster sessions are planned with suitable papers.

For registration and accomodation information, please see the above announcement.

The deadline for abstracts has passed. A preprint volume will be prepared and distributed at the conference.

For more information, contact: Col. Floyd Hauth, Program Chairperson, 1st Weather Wing/CC, Hickam AFB, HI 96818 (tel.: 808-449-1748). 
The program was published in the February 1989 Bulletin. $(5 / 88 ; r 3 / 89)$.

\section{Announcement}

\section{AMS Short Course on Hurricane Forecasting and Tropical Meteorology for the Media, May 31, 1989, Bal Harbour, Fla.}

An AMS Short Course on Hurricane Forecasting and Tropical Meteorology will be held 31 May 1989 at the Sheraton Bal Harbour Hotel, Bal Harbour Fla. The 19th Conference on Broadcast Meteorology being held 1-4 June 1989 will follow the course.

See the announcement on p. 320 in this issue for registration information and a tentative course schedule. $(12 / 88 ; r 3 / 89)$

\section{9th AMS Conference on Broadcast}

Meteorology, June 1-4, 1989, Bal Harbour, Fla. The 19th Conference on Broadcast Meteorology sponsored by the American Meteorological Society will be held at the Sheraton Bal Harbour Hotel 1-4 June 1989, preceded by the AMS Short Course on Hurricane Forecasting and Tropical Meteorology.

Papers were invited on all aspects of meteorology that have direct application to the broadcast industry. Emphasis is being placed on papers dealing with the extreme weather of 1988, the philosophy, ethics and liability of broadcast meteorology, astronomy, changes in radio, broadcast techniques, the evolving newspaper market, air-sea interaction, commodity forecasting, and the future of television weather presentations.

The deadline for abstracts has passed. For more information, contact: Program Chairman, Gary Ley, TV Meteorologist, WJAR-TV, 111 Dorrance St., Providence, R.I. 02903 (tel.: 401-751-5700 x186). (12/88;r2/89)

A preliminary conference program appears in this issue of the Bulletin, pp. 321-324.

\section{International Conference on Mountain Meteorology and ALPEX, June 5-9, 1989, Garmisch-Partenkirchen, Federal Republic of Germany}

An International Conference on Mountain Meteorology and ALPÈX will be held 5-9 June 1989 in Garmisch-Partenkirchen, upper Bavaria, Federal Republic of Germany, under the auspices of the German Meteorological Society. It is being organized by the German Aerospace Research Establishment (DFVLR-Oberpfaffenhofen) and will be cosponsored by the World Meteorological Organization, the American Meteorological Society, and other national and international agencies.

The conference will endeavor to review the advances in research on orographic influences in general and the latest scientific results of ALPEX in particular.

The main topics of the conference are 1) Three-dimensional flow over and around mountain complexes (including islands); 2) Severe mountain-induced winds; 3) Air flow, transport and diffusion over complex terrain; 4) Representation of mouniains and their effects in numerical forecast models (including gravity wave drag parameterization); 5) Mountain-induced cyclogenesis (including mesolows); 6) Orographic effects on fronts; 7) Orographically induced thermal circulations, convection and precipitation.

The deadline for abstracts has passed. For more information, contact: Dr. J. P. Kuettner, NCAR, P.O. Box 3000, Boulder, CO 80307, USA (tel.: 303-497-8922), or Dr. M. E. Reinhardt, Inst. Physik der Atmosphäre der DFVLR, D8031, Oberpfaffenhofen, P. Wessling, Fed. Rep. of Germany (tel.: 8153-28507).

Preprints of the extended abstracts will be available at the beginning of the conference. The editors of Meteorological and Atmospheric Physics have offered to devote two volumes ( 4 issues each) to the publication of selected conference papers after the usual review process. They are expected to appear in mid-1990.

The registration fee will be DM200 (students DM30). Attendees must make their own reservations through the tourist office of Garmisch-Partenkirchen. Information about this and other details are contained in a circular which can be requested from Dr. Reinhardt at the address and tel. listed above.

For more detailed information about the conference please refer to the January 1989 Bulletin. $(7 / 88 ; r 2 / 89)$

\section{Announcement}

\section{6th Annual Meeting of the Eastern Snow Conference, June 8-9, 1989, Quebec, Canada.} The 46th Annual Meeting of the Eastern Snow Conference will be held 8-9 June, 1989, with the American Meteorological Society as a cooperating organization.

Topics discussed at past meetings have included snow physics and chemistry, snow and ice management, snowmelt runoff, the impact of snow on climate and East Coast and Lake Effect snowstorms.

For the 1989 conference there will be two special sessions; one devoted to international snow hydrology and one dealing with hydro-production as a result of global climate change. In addition, there will be several general sessions dealing with various aspects of snow.

For further information, contact: Dr. Gerald Jones, Universite du Quebec, INRS EAU, CP 7500 Ste. Foy, Quebec G1V 4C7 (tel: (418) 654-2533); or James Foster, Goddard Space Flight Ctr., Greenbelt, MD 20771 (tel: (301) 2867096). (3/89)

\section{Second International Conference on School and Popular Meteorological Education, July 1989, Crystal City (Arlington), Va.}

The Second International Conference on School and Popular Meteorological Education, organized by the American Meteorological Society, will be held 12-16 July 1989 in Crystal City (Arlington), Va. The Royal Meteorological Society and the World Meteorological Society are cosponsors.

The conference is intended for all those involved in general (nonspecialist) meteorological and oceanographic education at the school and adult levels. It will focus on 
two themes: 1) The role of meteorology and oceanography in the formal science education of students; and 2) The general education of the public in the use of the services and products provided by national environmental services and the media. Individuals are invited to consult Weather Education, Proceedings of the First International Conference on School and Popular Meteorology (Royal Meteorological Society, 1985) to see the breadth of topics covered. Amateur observers and weather hobbyists with an interest in education are welcome and will find much to interest them.

Because of the diversity of topics to be addressed, the conference will have a mixed format. Presentations were solicited on the following topics: 1) What is being done and why - a survey of general meteorological and oceanographic education worldwide; 2) Communications, teaching, and learning techniques - the use of television, radio, visual aids, microcomputers, electronic bulletin boards, books, field courses, etc.; and 3) The future - what should be taught, how technology can best be applied, how the quality of textbooks can be improved, etc.

A number of speakers from industry, government, and the scientific and educational communities will be invited to highlight areas of particular interest. There will also be special sessions for presentations that focus on "hands-on" demonstrations of equipment and teaching aids or that provide opportunities for attendees to engage in practical work. Presentations of this type from teachers at all levels are especially encouraged.

The conference will also feature a display of current books, videotapes, computer software, and other educational materials suitable for use in schools and in programs for the general public.

Registration for the conference is $\$ 135$, with a special rate of $\$ 75$ for high school science teachers. This fee includes the preprint volume.

A block of rooms has been reserved at the Stouffer Concourse Hotel at special conference rates of $\$ 65 /$ single, $\$ 80 /$ double plus tax. The deadline for hotel reservations is 7 June, 1989, and the AMS urges that reservations be made early. Make arrangements directly with the hotel at 2399 Jefferson Davis Highway, Arlington VA 22202 (tel.: 703979-6800).

The deadline for abstracts has passed. Authors will be notified of acceptance by 15 March 1989. A preprint volume will be prepared and distributed at the meeting. Authors of accepted papers will receive information about format and submission deadlines, and special, large-format typing paper for preparation of manuscripts. All correspondence and abstracts should be addressed to Dr. John T. Snow, Dept. of Earth and Atmospheric Sciences, Purdue Univ., W. Lafayette, IN 47907, USA (tel.: 317-494-3284). $(10 / 88 ; r 2 / 89)$

\section{Fifth Scientific Assembly of the International Association of Meteorology and Atmospheric Physics (IAMAP), July 31-August 11, 1989, Reading, United Kingdom}

The IAMAP will hold its Fifth Scientific Assembly at the University of Reading, Reading, United Kingdom, 31 July11 August 1989. The Assembly will have four components: invited overview lectures, four major symposia, thirteen topical symposia, and a variety of workshops.

For complete descriptions of symposium contents and sponsors, please see the October 1988 Bulletin. The deadline for abstracts has passed.
The titles of proposed one- and two-day workshops, for which the number of participants will be limited, are Global Datasets; International Satellite Land Surface Climatology Project; Interpretation of Satellite and Radar Imagery, and Needs and Opportunities for Observational Studies and Numerical Prediction Models of Mesoscale Weather Systems.

An IAMAP Preprint volume will be available to Assembly participants. A range of IAMAP books relating to the major symposia and some of the topical symposia will be published after the assembly, along with Perspectives in Atmospheric Science, the latter being published jointly by the Royal Meteorological Society and IAMAP and containing the invited lectures and selected review articles given at the Assembly.

During the Assembly there will be a commercial exhibition, scientific excursions and social events, including a banquet at Hampton Court Palace. For further information about the assembly, registration, or accommodations, write to: Ross Reynolds, IAMAP 89, Dept. of Meteorology, Univ. of Reading, 2 Earley Gate, Reading RG6 2AU, United Kingdom. (4/88;r2/89)

\section{Symposium on Ice and Climate, August 21-25, 1989, Seattle, Wash.}

The Symposium on Ice and Climate, sponsored by the Glaciological Society, and co-sponsored by the American Geophysical Union and the American Meteorological Society will be held 21-25 August 1989 in Seattle, Wash. This meeting will be concerned with natural forms of ice on land and in the sea and will focus on 1) Information obtained from ice about past climates; 2) Physical processes by which ice influences climate change; and 3) Practical means by which ice effects can be incorporated into largescale climate models. Specific topics will include deduction of paleoclimate from ice properties, advance and retreat of glaciers and ice sheets, climate effects of sea ice-oceanatmosphere interaction, and implications of seasonal snow cover feedbacks for long-term climate change.

There will be both oral and poster sessions. The deadline for abstracts has passed. Authors will be notified of acceptance in early April 1989. The proceedings will be published by the Society in the Annals of Glaciology. Manuscripts for inclusion in the published proceedings are due 1 June 1989.

Additional information about the meeting and postsymposium tours to Cascade volcanoes or Alaskan glaciers may be obtained from the International Glaciological Society, Lensfield Road, Cambridge, CB2 1ER, England. (11/ $87 ;$ r2/89)

\section{WMO Technical Conference TECIMO-IV, Sept. 4-8, 1989, Brussels, Belgium}

The World Meteorological Organization of Instruments and Methods of Observation (CIMO) is organizing the quadrennial technical conference TECIMO-IV to be held 4-8 September 1989 in Brussels, Belgium. The conference will be hosted by the Royal Meteorological Institute of Belgium (RMI) and will be held in parallel with the COST-73 International Seminar on Weather Radar Networking (see Call for Papers following). 
The theme of the conference and also of the CIMO-X session, to be held during the following two weeks, is "Technology appropriate to users' needs." Papers were solicited on the following topics: 1) Sensors (new principles, improved reliability, environmental quality, stability); 2) Automatic weather stations (functional and technical specifications, operational experience); 3) Remote sensing (different types of radars, atmospheric sounding systems, satellite receiving stations); 4) Algorithms (data acquisition, presentation, automation); 5) Data quality (representativeness, quality assurance, standards); 6) Intercomparisons (international, regional and national, experimental results); 7) Network operation (calibration, maintenance, training); and 8) Integrated and interactive systems.

The deadline for abstracts had passed. Authors of accepted papers will be notified and will receive instructions for preparing papers, which will be due 1 May 1989. The conference proceedings will be published by WMO and distributed at the conference. All participants, including those not submitting papers, should have already informed the Organizing Committee of their intention to participate. Those who have will soon receive further information on traveling, hotel reservations, registration, and postconvention possibilities.

Common to both TECIMO-IV and the COST-73 Weather Radar Seminar, a quadrennial exhibition of meteorological equipment, METEOREX-89, is also being organized. Manufacturers of equipment and systems, suppliers of products and services, government agencies and users are invited to use the 1200-square-meter exhibition hall of the "Palais des Congrès" to display and demonstrate their products and services.

For further information, contact the Local Organizing Committee, RMI, Attn: Dr. A. Van Gysegem, Ringlaan 33, B-1180 Brussels, Belgium. (10/88;r2/89)

\section{International Conference on Modelling of Global Climate Change and Variability, Sept. 11-15, 1989, Hamburg, Fed. Rep. of Germany}

The International Conference on Modelling of Global Climate Change and Variability, cosponsored by the International Association of Meteorology and Atmospheric Physics (IAMAP) of the International Union of Geodesy and Geophysics (IUGG), The Deutsche Meteorologische Gesellschaft, the American Meteorological Society, the World Meteorological Association, the Deutsche Forschungsgemeinschaft, and the Bundesministerium fur Forschung und Technologie, will be held 11-15 Sept., 1989, at the University of Hamburg in Hamburg, Fed. Rep. of Germany. The Programme Committee is cochaired by Dr. G. Fischer and Dr. K. Hasselmann.

Papers were solicited on 1) performance of global models of the atmosphere, 2) performance of global models of the ocean, 3) development of coupled models, 4) climate sensitivity experiments, 5) modelling of paleo-climate, and 6) prediction of anthropogenic climate change. In addition, invited papers on "The current state of the ocean/atmosphere/ice system" and "Diagnosis of global climate variability and global climate trends" will be presented.

The deadline for abstracts has passed. Copies of final abstracts will be distributed at the beginning of the conference. It is envisaged that authors will be able to submit their papers for publication in a special issue of Climate Dynamics.
For further information, contact: Dr. L. Dumenil, Meteorologisches Institut der Universitat Hamburg, Bundesstrasse 55, D-2000 Hamburg 13, Fed. Rep. of Germany. (11/ $88 ; r 3 / 89)$

\section{Call for Papers}

\section{WMO Technical Conference on Monitoring and Assessment of Changing Composition of the Troposphere, October 1989, Bulgaria.}

The WMO Technical Conference on Monitoring and Assessment of Changing Composition of the Troposphere, to be held in October 1989, is being called as a worldwide forum for presentation of individual studies and broad discussion of related issues.

This Technical Conference will precede the International Conference (FRG, 16-20 Oct. 1989), and the two will complement, not overlap each other by subject.

The deadline for abstracts is 31 March, 1989.

WMO is planning to publish 4-page extended summaries of final papers which will be distributed at the conference. The manuscript deadline for accepted abstracts is 1 August 1989.

For more detailed information on the conference and submission of abstracts, contact: WMO, Attn: Environment Div., P.O. Box 5, 1211 Geneva 20, Switzerland.

\section{2th Conference on Weather Analysis and Forecasting, Oct. 2-6, 1989, Monterey, Calif.} The Twelfth Conference on Weather Analysis and Forecasting, cosponsored by the American Meteorological Society and the National Weather Association, will be held 2-6 October 1989 (please note revised meeting date) in Monterey, Calif. at the Naval Postgraduate School. The AMS Committee on Weather Analysis and Forecasting is responsible for the technical program, and the AMS Monterey Peninsula Chapter will be the local host. It is possible that there will be joint sessions with the 11th Conference on Probability and Statistics which will be co-located with the conference (see following Call for Papers listing).

Papers were solicited on all aspects of weather analysis and forecasting, as well as those that will emphasize recent advances and future opportunities in short-range and medium-range forecasting. Satellite Meteorology and Oceanography is included as an additional meeting topic.

Both oral and poster sessions are planned. The Program Committee and the Local Arrangements Committee will make a special effort to ensure interesting, well-organized poster sessions in which authors will have more than ample opportunity to exhibit the results of their work.

The deadline for abstracts has passed Manuscripts are due 23 May 1989. For more information, contact: Carlyle H. Wash, Program Chairperson, Dept. of Meteorology, Code 63Wx, Naval Post-graduate School, Monterey, CA 93943-5000 (tel.: 408-646-2295).

Instructions and special typing paper will be furnished to the authors of accepted papers. A complete cameraready manuscript should be no more than six pages in length, including diagrams and photographs. Authors are asked to refer to "Meeting Procedures for Authors" follow- 
ing the Calendar of Meetings in the Bulletin. Again, manuscripts are due no later than 23 May 1989. Page charges will be assessed to help defray printing costs. Attendees will receive a preprint volume at the time of registration. $(9 / 88 ; r 3 / 89)$

\section{Call for Papers}

\section{1th Conference on Probability and Statistics, Oct. 2-6, 1989, Monterey, Calif.}

The Eleventh Conference on Probability and Statistics, sponsored by the American Meteorological Society, will be held 2-6 October, 1989, in Monterey, Calif. at the Naval Postgraduate School. The AMS Committee on Probability and Statistics is responsible for the technical program, and the AMS Monterey Peninsula Chapter will be the local host.

Papers are solicited on all aspects of probability and statistics that have relevance to the atmospheric sciences. In addition, review papers are planned that will emphasize recent advances and current applications of probability and statistic forecasting. Furthermore, a few joint sessions with the Weather Analysis and Forecasting Conference also are planned (e.g., a session on $\mathrm{Al}$ in weather and forecasting). Lastly, plans are being considered for a short course on a topic of interest to both meteorologists and statisticians (e.g., graphical display of data) for the Sunday (Oct. 1) prior to the conference.

Acceptance of papers will be based on the author's abstract, a 300- to 400- word synopsis, which should include the primary methodology and results of the paper and the relevance of those results. Authors or groups desiring to present more than one paper are urged to assign a priority to the abstracts submitted in case the volume of papers forces the Program Committee to limit the number of presentations to one per author.

Both verbal and poster sessions are planned. Authors should indicate their preference when submitting abstracts. The Program Committee and the Local Arrangements Committee will make a special effort to ensure interesting, wellorganized poster sessions in which authors will have more than ample opportunity to exhibit the results of their work. Every effort will be made to assign papers to sessions according to the format requested by the author. However, since the relevance of the paper to the theme of the session will take precedence over the requested format, authors should indicate if they will agree to a poster presentation if asked.

Titles and reviewer's abstracts should be submitted by 14 April 1989. Authors will be notified in early May 1989 regarding acceptance of their papers.

Instructions and special typing paper will be furnished to the authors of accepted papers. A complete cameraready manuscript of not more than six pages in length, including diagrams and photographs, must be received at AMS headquarters no later than 23 June 1989. Authors are asked to refer to "Meeting Procedures for Authors" following the Calendar of Meeting in the Bulletin. Page charges will be assessed to help defray printing costs. Attendees will receive a preprint volume at the time of registration.
For more information, contact: Dr. John Flueck, NOAA/ ERL/FSL, R/E22, 325 Broadway, Boulder, Colo., 80303 (tel.: 303-497-6863). (1/89;r3/89)

\section{Third International Conference on Southern Hemisphere Meteorology and Oceanography, Nov. 13-17, 1989, Buenos Aires, Argentina}

The Third International Conference on Southern Hemisphere Meteorology and Oceanography, sponsored by the American Meteorological Society and the Argentinian Center of Meteorologists, and cosponsored by WMO, the University of Buenos Aires, and the National Weather Service of Argentina, will be held 13-17 November 1989 in Buenos Aires, Argentina.

Papers were solicited on all aspects of Southern Hemisphere meteorology and oceanography that are of general interest and papers dealing with observational analyses, empirical studies, and modeling were encouraged. For information on specific session topics and members of the program committee, please refer to the January 1989 Bulletin.

The deadline for abstracts has passed.

A preprint volume of extended abstracts will be prepared and distributed at the conference. Instructions and special typing paper will be furnished to authors of accepted papers. A complete camera-ready manuscript of no more than four pages (waived for invited speakers), including diagrams, must be received at AMS headquarters (45 Beacon St., Boston, MA 02135, USA) no later than 1 July 1989. Page charges will be assessed to help defray printing costs.

Current round trip discount airfare from New York to Buenos Aires is about (US) $\$ 700-(U S) \$ 800$ for stays of $7-$ 21 days. Current hotel prices start at (US)\$20. Some limited travel funds may become available from U.S. sources for nongovernment U.S. scientists and from WMO.

The mean temperature in Buenos Aires in November is $20^{\circ} \mathrm{C}$ with a mean maximum of $25^{\circ} \mathrm{C}$ and minimum of $15^{\circ} \mathrm{C}$. November has an average of eight days of rain. (1/ $88 ; r 3 / 89$ )

\section{Announcement}

\section{Symposium on Global Change Systems/Panel on Interdisciplinary Education in the Earth Sciences, January 1990, Place to be Determined}

The Symposium on Global Change Systems/Panel on Interdisciplinary Education, sponsored by the American Meteorological Society and cosponsored by the American Geophysical Union and the Ecological Society of America, will be held in January 1990 at a location to be determined. The Symposium will be held in conjunction with the 70th AMS Annual Meetings and the meetings on Hydrometeorology, Climate Variations, Sea-Air Interaction/Chemistry, and Interactive Information and Processing Systems. This is a preliminary announcement; detailed information will appear in the Bulletin as it becomes available. 


\section{AMERICAN METEOROLOGICAL SOCIETY PRESENTS \\ A VIDEOTAPE SERIES FROM THE SHORT COURSE ON RADAR AND SATELLITE APPLICATIONS TO MESOSCALE METEOROLOGY}

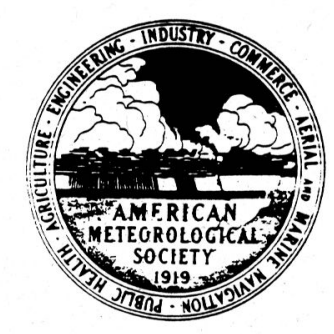

As a service to its members and the meteorological community, the American Meteorological Society presents five videotapes and the course notes for the short courses held at the 18th AMS Conference in Chicago, June 16, 1988. The five subject areas deal with the state-of-the-art changes occurring in meteorology. The videotapes will give you an excellent opportunity to learn from the experts working directly with these new technologies and to further your understanding of the impact of technological advances on mesoscale weather forecasting.

The five topics covered include:

1. Use of Radar and Satellite Data for Mesoscale Forecasting at the National Severe Storms Forecast Center (NSSFC). Fred Ostby, Director, NSSFC, Kansas City, Missouri.

2. The Promise of NEXRAD. Les Lemon, Manager, NEXRAD Operations Capability Assurance Section, UNISYS Corporation, Independence, Missouri.

3. Mesoscale Forecasting in an Operational Setting Using an Advanced Interactive Workstation. Carl Bullock, Meteorologist PROFS, and Larry Dunn, Research Meteorologist, WSFO, Denver, Colorado.

4. The Four W's of Satellite Imagery From a Subsynoptic Perspective: What, Why, Where, and When.

H. Michael Mogil, Chief, Training and Info. Svcs. Branch, NESDIS, Washington, D.C.

5. The Impact of New Technologies on NWS Operations and Services at Oklahoma City, Oklahoma. Larry Mooney, Deputy Meteorologist-in-Charge, WSFO, Norman, Oklahoma.

The tapes are available in: __ VHS _ BETA _ 3/4" U-Matic

Please indicate which format you prefer. Orders should be mailed with check or purchase order directly to: EUSTIS ENTERPRISES, 3307 Quesada Street NW, Washington, D.C. 20015-1664.

Please Send:

$\begin{aligned} \$ 175.00 & \text { Single Module \# } \\ 325.00 & \text { Total Series } \\ 30.00 & \text { Add'1 Workbooks } \\ 200.00 & \text { Complete Set (Special price for Attendees Only) }\end{aligned}$

Total Enclosed:

The cost includes shipping and handling. One complete workbook covering all five modules is included with each order.

Name/Address: 


\section{Bring the atmosphere to life on your wall...}

THE ATMOSPHERE -a wall chart. SIze $140 \times 85 \mathrm{cms}, 55 \times 33$ inches.

By: Kelth Foley, Produced In consultation with the Amerlcan Meteorological Sociely

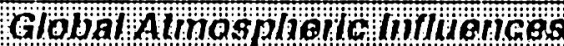 \\ : \\ Dlagrams the major global atmospherlo influences, Including global cliculation, solar radlation, the rotalion of the earth, the hydrologlo cyole and more.}

\section{Meleorological nougro}

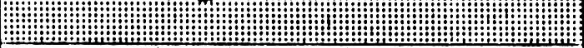

Doscribes tho forces which cause air masses to move, such as cold fronts, warm fionts, orographle lifting, land and sea breezes, rellof winds and fog.

\section{Severe Wertio}

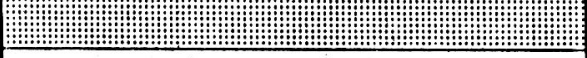

Illustrates the baslc types of severe stoms, including hurricanes, tomadoes, waterspouts, and thunderstorms.

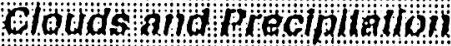
$\begin{array}{r}8 \\ -88 \& 8 \\ \hline\end{array}$ Doplcts the ten basle types of clouds, showing thelr elevatlons. Alliustrates varlous types of precipltation (sleet, snow, hall, oto.) and explains the conditlons under which they form.

\section{Mteleorologlotalojotrs} : Shows examples of baslo optic phenomena such as waterdrop optlcs (ralinbows), ice crystal optics (haloes) and femperature gradient optlcs (mirages), all with brlol descriptlons.

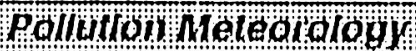

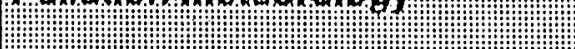

Provides exaniples of acld raln and smog, discussing their effects on the environment. A table summarizes the interactions between pollution

\section{Avtlon Meteorology}

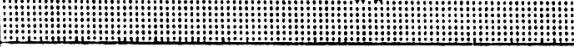

Illustrales weather phienomena found in aviation weather reports, Including squall Iines, gust tronts, wind shear, and types of lce accretion. and lifo forms.

For the first time ever, here is a wall chart that depicts all of the major weather phenomena used by meteorologists, aviators and space scientists. The chart illustrates each weather system with a diagram and brief explanation. It shows spectacular color photographs of the basic cloud types, frontal systems, and more. Intended for students, hobbyists and professionals alike, THE ATMOSPHERE will prove invaluable as an easy wall reference.

Prices are as follows:

\begin{tabular}{|llc|}
\hline Quantity & Price & Shipplng \& Handling \\
\hline $1-9$ & $\$ 14.50$ & $\$ 3.00$ \\
$10+$ & $\$ 122.50 / 10$ & $\$ 6.00 / 10$ charts
\end{tabular}

Prices effective July 1, 1988, and subject to change without notice.

Send orders with check to: American Meteorological Society 45 Beacon Street Boston, MA 02108

All orders must be prepaid. Payment for orders outside the United States must be made by a draft on a U.S. bank or by an international money order payable in U.S. dollars. 